\title{
ETS Homologous Factor
}

National Cancer Institute

\section{Source}

National Cancer Institute. ETS Homologous Factor. NCI Thesaurus. Code C26155.

ETS homologous factor (300 aa, $\sim 35 \mathrm{kDa}$ ) is encoded by the human EHF gene. This protein plays a role in the regulation of gene transcription. 